\title{
Direct evidence on risk attitudes and migration
}

Citation for published version (APA):

Jaeger, D. A., Dohmen, T. J., Falk, A., Huffman, D., \& Sunde, U. (2008). Direct evidence on risk attitudes and migration. Researchcentrum voor Onderwijs en Arbeidsmarkt, Faculteit der Economische Wetenschappen. ROA Research Memoranda No. 11 https://doi.org/10.26481/umaror.2008011

Document status and date:

Published: 01/01/2008

DOI:

10.26481/umaror.2008011

Document Version:

Publisher's PDF, also known as Version of record

\section{Please check the document version of this publication:}

- A submitted manuscript is the version of the article upon submission and before peer-review. There can be important differences between the submitted version and the official published version of record.

People interested in the research are advised to contact the author for the final version of the publication, or visit the DOI to the publisher's website.

- The final author version and the galley proof are versions of the publication after peer review.

- The final published version features the final layout of the paper including the volume, issue and page numbers.

Link to publication

\footnotetext{
General rights rights.

- You may freely distribute the URL identifying the publication in the public portal. please follow below link for the End User Agreement:

www.umlib.nl/taverne-license

Take down policy

If you believe that this document breaches copyright please contact us at:

repository@maastrichtuniversity.nl

providing details and we will investigate your claim.
}

Copyright and moral rights for the publications made accessible in the public portal are retained by the authors and/or other copyright owners and it is a condition of accessing publications that users recognise and abide by the legal requirements associated with these

- Users may download and print one copy of any publication from the public portal for the purpose of private study or research.

- You may not further distribute the material or use it for any profit-making activity or commercial gain

If the publication is distributed under the terms of Article $25 \mathrm{fa}$ of the Dutch Copyright Act, indicated by the "Taverne" license above, 


\title{
Direct Evidence on Risk Attitudes and Migration
}

\author{
David A. Jaeger* \\ City University of New York Graduate Center and IZA \\ Thomas Dohmen \\ ROA, Maastricht University, IZA, and DIW \\ Armin Falk \\ University of Bonn, IZA, CEPR, and DIW \\ David Huffman \\ Swarthmore College and IZA \\ Uwe Sunde \\ University of St. Gallen, IZA, CEPR, and DIW \\ Holger Bonin \\ $Z E W$
}

November 2008

*Corresponding author. Address: Ph.D. Program in Economics, Graduate Center, City University of New York, 365 Fifth Avenue, New York, NY 10016. Email: djaeger@gc.cuny.edu

Acknowledgements: The authors thank Deborah Cobb-Clark and participants of seminars and conferences at the Australian National University, the Berlin Labor Network, the European Association of Labor Economics meetings (Prague), Econometric Society European Meetings (Budapest), ESRI (Dublin), Hebrew University, IZA, Rutgers University, RWI-Essen, Verein für Socialpolitik, and Virginia Commonwealth University for comments. David Jaeger thanks IZA for support while he worked on this paper. 


\begin{abstract}
It has long been hypothesized that individuals' migration propensities depend on their attitudes towards risk, but the empirical evidence, to the extent that it exists, has been indirect. In this paper, we use newly available data from the German Socio-Economic Panel to measure directly the relationship between migration propensities and attitudes towards risk. We find that individuals who are more willing to take risks are more likely to migrate between labor markets in Germany. This result is robust to stratifying by age, sex, education, national origin, and a variety of other demographic characteristics. The effect is substantial relative to the unconditional migration propensity and compared to the conventional determinants of migration. We find no evidence that these findings are the result of reverse causality.
\end{abstract}

Keywords: risk aversion, migration, Germany

JEL Classification: J61, D81, R23 
Geographic mobility plays an important role in the efficient functioning of markets. Moving people and capital to where they can be most productively utilized is essential to any working economy. Because migrants may "grease the wheels" of the labor market (Borjas, 2001) it is important to understand the determinants of geographic mobility. While it has long been hypothesized that individuals' willingness to take risks may play an important role in migration, and therefore in the efficient functioning of labor markets, there is no direct evidence on whether risk attitudes do, in fact, influence individuals' migration decisions. This paper attempts to fill this gap in the literature.

To motivate why attitudes towards risk taking might be important for the migration decision, consider that individuals derive utility from consumption and leisure. It is quite reasonable to assume that individuals have more information about income, consumption, and leisure opportunities in their present location compared to other potential locations. This relatively greater uncertainty over some or all of the arguments of the utility function is one sense in which migration is a fundamentally risky activity, leading to a tendency for individuals who are more willing to take risks to have a higher probability of migrating.

The direction of the relationship between risk attitudes and migration is potentially ambiguous, however. Risk attitudes could also potentially affect migration decisions if risk-averse individuals desire to live in regions with (known) lower variances of the income distribution. More risk-averse individuals might favor locations with lower variances to avoid uncertainty in income, while lower risk-averse individuals may use migration as a means of improving their chances of receiving a higher-than-average wage. 1

In the modern German context that we examine, we consider the former argument regarding imperfect information to be more applicable. To be sure, there are some differences in income variances

\footnotetext{
${ }^{1}$ Most of the previous literature on the role of risk attitudes for migration has focused on this sorting argument, and on migration as a means of diversification of family income, largely in developing countries. See, for example, Smith (1979), Levhari and Stark (1982), Katz and Stark (1986), Xu (1992), and Daveri and Faini (1999), among others. Heitmueller (2005) posits a model in which risk averse individuals are less likely to migrate, and calibrates the model using actual data, but does not estimate how risk aversion determines migration propensities.
} 
across regions in Germany, but they are small compared to those that exist in developing countries or between developing and developed countries. ${ }^{2}$ We therefore hypothesize that general uncertainty about other locations is the more important channel through which risk attitudes determine intra-German geographic mobility, and that the average mover is relatively more willing to take risks. ${ }^{3}$

To our knowledge, no previous empirical study examines the relationship between migration and risk attitudes, directly measured. ${ }^{4}$ We use newly available data from the German Socio-Economic Panel (SOEP) that includes direct measures of attitudes towards risk, and find that being more willing to take risks is a positive, statistically significant, and quantitatively important determinant of migration. We find that being relatively willing to take risks is associated with an increase of at least 1.5 percentage points in the probability of ever migrating between 2000 and 2006, even after conditioning on individual characteristics. This effect is substantial relative to the unconditional migration propensity of 5.8 percent. We also present results indicating that our findings are highly unlikely to be the result of reverse causality (i.e. that migration causes changes in risk attitudes).

\section{Data}

The SOEP is a representative panel survey of the resident adult population of Germany that began in western Germany in 1984 and was expanded to include eastern Germany in $1990 .^{5}$ The SOEP surveys the head of each household in the sample as well as all other household members over the age of 17 on a wide variety of economic, political, and attitudinal issues. Of most interest to us are the 2004 and 2006 waves of the SOEP, which contain a novel set of questions about individuals' risk attitudes.

\footnotetext{
${ }^{2}$ Moreover, Gottschalk and Smeeding (1997) show that Germany has lower income inequality than many other developed countries.

${ }^{3}$ We present evidence below that Germans perceive migration as a risky endeavor.

${ }^{4}$ In work that post-dates ours, Conroy (2007) has recently presented work that uses a direct measure of risk attitudes in Mexico. Using the Mexican Family Life Survey, he finds that that there is a positive correlation between risk aversion and migration for young Mexicans.

${ }^{5}$ For a detailed description of the SOEP, see Wagner et al. (1993), and Schupp and Wagner (2002). Additional details can be found at http://www.diw.de/english/sop/ (last seen 14 February 2007).
} 
Our primary focus is on the question that asked individuals for their attitude towards risk in general, allowing respondents to indicate their willingness to take risks on an eleven-point scale, with zero indicating complete unwillingness to take risks, and ten indicating complete willingness to take risks. ${ }^{6}$ Our analysis uses responses on the scale as an index of willingness to take risks (which we refer to as the "risk index") as well as a binary indicator for whether someone chose a value of six or higher on the scale (which refer to as the "risk indicator). ${ }^{7}$ The latter measure minimizes potential problems from different use of scales by the survey respondents. We view the preferences represented by the responses to these questions as fixed over the period of time in our sample, but also investigate the possibility of reverse causality, such that migration affects risk attitudes, by using the 2006 wave of the SOEP that includes the risk question for a second time.

The risk question we use here has been experimentally validated and shown to be a reliable measure of an individual's actual propensity to take risks. Dohmen et al. (2005) used a pool of 450 subjects with characteristics comparable to the respondents of the SOEP who answered the same general risk question from the SOEP questionnaire that is used in this paper. After completing the survey questionnaire, these subjects participated in a real-stakes lottery experiments. The responses to the general risk question turned out to be good predictors of actual risk taking behavior in the paid experiment. Dohmen et al. (2005) also show that responses to this risk question predict other behaviors involving risk, such as holding stocks, being self-employed, or smoking. Thus we are confident that the general risk question is a behaviorally valid measure of an individual's underlying attitude towards risk. ${ }^{8}$

\footnotetext{
${ }^{6}$ The exact wording of the question (translated from German) is: "How do you see yourself: Are you generally a person who is fully prepared to take risks or do you try to avoid taking risks? Please tick a box on the scale, where the value 0 means: 'not at all willing to take risks' and the value 10 means: 'very willing to take risks'." German versions of all risk questions are available online, at http://www.diw.de/deutsch/sop/service/fragen/fr2004/personen_2004.pdf (last seen 14 February 2007).

${ }^{7}$ Robustness checks conducted by Dohmen et al. (2005) suggest that choosing a threshold of six and above on the eleven point scale does not affect the behavioral validity of the responses.

${ }^{8}$ The SOEP also asked about risk attitudes in other domains such as career and finance. We explore their relationship with migration in Jaeger, et al. (2007).
} 
The smallest geographic unit defined in the publicly available version of the SOEP is the Raumordnungsregion (literally, "spatial district", although we will refer to them as "regions" in the rest of the paper). Germany is divided geographically into 97 such regions, which are defined by the Bundesamt für Bauwesen und Raumordnung (Federal Office for Building and Regional Planning) and reflect an aggregation of Landkreise and kreisfreie Städte (administrative districts, something akin to counties in the U.S.), taking into account economic agglomeration and commuting flows. Each region captures a center of economic activity and its surrounding area and corresponds to a labor market. We define a migration as a move from one region to another. ${ }^{9}$

For our analysis, we restrict the sample to the 2000 through 2006 waves of the SOEP, including data since the most recent survey refreshment in 2000, in order to have a large balanced panel and also provide a sufficient number of observed migrations. We concentrate on prime-age individuals who were between 18 and 65 years of age during the entire survey period, leaving us with a sample of 10,115 individuals with 6 years of migration data. ${ }^{10}$

\footnotetext{
${ }^{9}$ We have also estimated the models in the paper using definitions of moves based on distance as well as between German Federal States (Bundesländer). The results are all qualitatively similar. When looking only at intra-regional moves, i.e. in which individuals changed dwelling but not Raumordnungsregion, we find that risk attitudes are substantially less important determinants. This supports our argument that what is primarily driving the results is uncertainty about other regions. See Jaeger, et al. (2007) for these results.

${ }^{10}$ This implies that only individuals born between 1940 and 1983 are contained in our sample. We eliminate from the sample individuals who had missing information on any of the variables used in the analysis as well as 20 individuals whose information on moving dwelling and moving region was inconsistent. Note that because an individual has to be in our sample in 2004 in order to have answered the risk question, any attrition in our sample that we can relate to risk attitudes occurs only over two years. Nevertheless of the 106 individuals who we observe in 2004 but leave the sample in 2005 or 2006, the mean of the risk index is 4.76 , versus 4.52 for individuals who remain in the sample for the entire period (this difference is not statistically significantly different from zero). The averages of the risk indicator for the attriters and nonattriters sample are 0.443 and 0.324 , respectively, which are statistically significantly different from one another. One should keep in mind, however, that most sample attrition occurs because individuals have moved and cannot be found by the SOEP interviewers. Thus, the attrition bias in our results would tend to be negative (i.e. the true relationship between risk attitudes and migration would be more strongly positive than our results indicate), and therefore our estimated effects of risk attitudes on the propensity of migrating should be taken as lower bounds of the true effects.
} 


\section{Risk Attitudes of Migrants and Non-Migrants}

Figure 1 shows the distribution of responses to the general risk question for "movers" (individuals who changed region at least once between 2000 and 2006) and "stayers" (individuals who did not change region in that period). While both distributions have a modal value of 5 on the 11-point scale, the distribution for movers has less weight in the left hand tail and more weight in the right hand tail. A greater proportion of movers than stayers clearly respond that they are relatively more amenable to taking risks.

In Table 1 we present for movers and stayers the average of the risk index as well as the share of the sample for which the risk indicator is equal to one, stratified by a variety of demographic characteristics. As reflected in Figure 1, the averages of the risk index and risk indicator are substantially larger for the 5.8 percent of the sample who moved than for those who never moved within the sample

period. Moreover, those who moved more than once are more risk-friendly than those who moved only once. These results are a first strong indication (albeit not conditional on any individual characteristics) in favor of the hypothesis that migrants are less risk-averse than non-migrants.

Across nearly all of the demographic categories (sex, age, education, marital status, and place of origin) we find strikingly consistent results that movers are more willing to take risks than stayers regardless of the risk measure we used. Roughly speaking, for most of the demographic groups, 10 to 15 percent more of the movers in our sample indicate being relatively more willing to take risks than do stayers. Note, too, that the migration propensities differ substantially across the various demographic groups, in the expected direction - older individuals are less likely to migrate, those who are married are less likely to migrate, and better-educated individuals are more likely to migrate. Nevertheless, the difference in risk attitudes between the movers and stayers is remarkably similar and consistent regardless of the demographic group. 
We also examine how risk attitudes affect moves motivated by different reasons. The bottom panel of Table 1 presents the average of the risk measures by different reasons for migration (family, job, housing, or other reasons). These categories are non-exclusive, i.e., individuals can state several reasons for moving. ${ }^{11}$ Individuals who move for family reasons (e.g. moving out of one's parents' house, separating from a spouse or partner) are relatively more amenable to taking risks than those who move for other reasons, although they are followed closely by individuals who move for job reasons. ${ }^{12}$ Regardless of the reason for migrating, however, all movers are more willing to take risks than individuals who do not move.

To support our assertion that migration is perceived as a risky endeavor, we surveyed 250 randomly sampled Germans, as part of a pre-test for the 2008 wave of the SOEP, regarding their perception of uncertainty when moving. Respondents were asked whether they agreed with the statement that moving between towns was associated with taking a risk; responses were coded on a scale from 0 to 10, with 0 meaning "do not agree at all" and 10 meaning "perfectly agree." We present the distribution of their responses in Figure 2. On average, they reported that moving between towns was a risky endeavor (the average response was 5.6), with more than half (52 percent) reporting a value of between 6 and 10 while a substantially smaller share (32.5 percent) reported a value between 0 and 4 . Additional questions in the pre-test indicated that the perceived risk of moving was associated with uncertainty regarding work as well as friendships. Moreover, the respondents' perceptions the riskiness of moving were statistically unrelated to our measures of risk attitudes, indicating that our measure of risk preferences are distinct from perceptions of the riskiness of migration. ${ }^{13}$

\footnotetext{
11 Forty percent of the movers in Table 1 give multiple reasons for moving.

12 These averages do not control for age. This result obtains because individuals who move for family reasons tend to be younger than those who moved for job reasons, and younger individuals also more willing to take risks, .

${ }^{13}$ Summaries of these additional results are available from the authors by request.
} 


\section{Risk Attitudes as Determinants of Migration}

We have seen in Table 1 that risk attitudes are correlated with a variety of personal characteristics, some of which may be simultaneously determined with migration. In Table 2 , we present marginal effects from estimating probit models where the dependent variable is an indicator of whether the individual ever moved across regions during 2000-2006. In columns (1) through (3) we present results using our risk index as the measure of risk attitudes, while in columns (4) through (6) we use the binary risk indicator described above; both measures are based on responses to the risk question in the 2004 wave. In columns (2) and (5) we control for factors that are conceivably exogenous to an individuals mobility decisions and that are not related to their current location (sex and age) while in columns (3) and (6) we control for additional variables that may be jointly determined with migration decisions (marital status and years of education) as well as variables that may determine an individual's initial location (origin/nationality).

In all six models we find statistically significant evidence that individuals who are relatively more willing to take risks are also more likely to move. In column (1) we estimate that a one-unit change in the risk index increases the probability that an individual migrates between labor markets by 0.64 percent. This implies an increase in the probability of moving of 1.7 percentage points for a one standard deviation (2.7 point) increase in the willingness to take risks. Relative to the unconditional migration probability of 5.8 percent, this effect is quite substantial. Similarly, in column (4) where we use the risk indicator, we find that the probability of migration is about 3.1 percentage points higher (or more than half of the unconditional probability) for individuals who are relatively more willing to take risks.

In columns (2) and (5) we include age and sex as covariates, because the results in Table 1 clearly indicate that these characteristics are strongly related to risk attitudes. Given the strength of the correlation between risk, age and sex, it is not surprising that the estimated coefficients on our risk measures decline, in both cases by approximately one third. Both measures remain statistically 
significantly different from zero at any conventional level, however. Using the risk indicator, individuals who are relatively more willing to take risks have a migration probability 2.1 percentage points higher than individuals who are not, an effect that is about half of the unconditional migration probability.

Controlling for marital status, education, and place of origin in columns (3) and (6) reduces the effect of risk attitudes on the probability of migration by about half compared to the models in which we do not include any additional covariates and by about a third compared to the models in which we included only age and sex. These variables may, in part, be jointly determined with migration. Nevertheless, the effect of risk attitudes on the probability of migrating is still quantitatively important and statistically significant. Roughly speaking, the partial effect of the risk indicator is equivalent to about three years of education and about three times more important than being female in determining whether an individual migrates. Being relatively more willing to take risks is only about half as important (in absolute value) as being married, however. ${ }^{14}$

While economists usually assume that preferences are stable over time and place, another concern is that most of the observed migrations in these data occur before the risk questions were posed in the 2004 wave and that our results might possibly be an artifact of reverse causality. Through a process of positive feedback, successful migration could possibly make individuals more likely to respond that they are willing to take risks. To address this concern, in Table 3 we present results from estimating the same models from Table 2, using as the dependent variable a) an indicator for those who migrated before the questions were asked, i.e. any time between 2000 and 2004, b) an indicator for those who migrated after the questions were asked (i.e. between 2004 and 2006), and c) the same as b), but

\footnotetext{
${ }^{14}$ Adjusting for the clustering of multiple observations from the same household had very little effect on the estimated standard errors and did not alter in any way the conclusions of hypothesis tests on them. We find a similarly positive and statistically significant relationship between average risk attitudes within a household and migration when we run similar regressions at the household level, as well as when we run individual-level regressions separately for men and women. We have also estimated the models from Table 2 controlling for age and education non-parametrically (i.e. with dummy variables for each year of age and each year of schooling) as well as including dummy variables for occupation and current region in 2000. The coefficients on our risk measures were virtually unchanged and remained statistically significant at any conventional level. All of these additional results are available from the authors by request.
} 
eliminating individuals from the regression who had also migrated between 2000 and 2004, prior to the question being asked. The top panel of Table 3 presents results for using the risk index; we have also estimated these models with the risk indicator, with similar results. The first column gives the sample size, and the second column gives the unconditional probability of migrating (i.e. the share of the sample that moved in the indicated period).

While the magnitudes of the coefficients in the ex ante and ex post regressions vary because the unconditional probability of migrating differs, in both cases risk attitudes are an important determinant of migration. This holds in the ex post regressions even when we remove individuals from the sample who had migrated previously. Indeed, relative to the unconditional probability of migrating, it appears that risk attitudes were more important in determining migration after the risk questions were asked than before.

As a further check for reserve causality, we use repeated information on risk attitudes from the 2006 wave of the SOEP and directly estimate the effect of migration on (the change in) risk attitudes after the move. ${ }^{15}$ The results in the bottom panel of Table 3 reveal that the fact that an individual migrated between 2004 and 2006 does not significantly affect the observed change in risk attitudes (line d) or the level of risk attitudes in 2006 when controlling for risk attitudes before the move in 2004 (line e). Given the strength of this evidence we therefore conclude that risk attitudes are a determinant of migration and not vice versa.

\section{Conclusions and Implications}

In this paper we provide the first direct evidence that individuals' risk attitudes affect their migration propensities. While relatively few Germans migrate across labor markets (about 1.1 percent

\footnotetext{
${ }^{15}$ Dohmen, et al. (2007) explore the stability of risk preferences between 2004 and 2006 in greater detail. In our sample of 10,108 individuals who responded to both questions, the correlation between the two measures of the risk index was 0.48 and the correlation between the two measures of the risk indicator was .38, with both correlations being statistically significantly different from zero at any conventional level. Seventy-two percent of the respondents have the same response in 2004 and 2006 in the risk indicator.
} 
per year in our sample), risk attitudes appear to play an important role in determining who does and does not move from one labor market to another. Being willing to take risks positively and significantly affects the probability of migration. Roughly speaking, the marginal effect of our indicator of being relatively willing to take risks is about 22 to 55 percent of the unconditional annual probability of migrating between labor markets. We find no evidence that this is due to reverse causality between migration and risk attitudes.

Labor mobility is important for the efficient functioning of labor markets. The available evidence suggests that differences in risk attitudes may, in part, explain different rates of geographic mobility observed in Germany versus the U.S. Our results suggest that individuals who are relatively more likely to take risks are also more willing to migrate. Using the same survey question to measure willingness to take risks in a survey that is representative of the U.S. population, Fehr et al. (2006) find evidence that Americans are substantially more willing to take risks than Germans, with a 2.2 point difference in the average response to the general risk question. Ceteris paribus, this difference in the risk scale would have led to a roughly 0.6 to 1.4 percentage point increase in the share of our sample that moved between 2000 and 2006, using the results in Table 2. This is substantial, relative to the unconditional migration probability of 5.8 percent in our sample.

The difference in risk endowments across countries may partially explain the greater mobility of Americans and why the U.S. labor market, in general, performs better than European labor markets risk attitudes might actually help to "grease the wheels" of the U.S. labor market. This, of course, raises the question of why risk attitudes might differ substantially across countries. One explanation is that the U.S. was founded relatively more recently, by waves of immigrants who were likely to be risk takers. In a recent paper, Dohmen, et al. (2006) showed that risk attitudes are correlated across generations. The transmission of risk attitudes from parents to children could explain the persistence of the difference in 
risk attitudes across countries over time. Future research on cross-national attitudes towards risk taking will be able to probe this question further. 


\section{REFERENCES}

Borjas, George J. (2001) "Does Immigration Grease the Wheels of the Labor Market?" Brookings Papers on Economic Activity, 2001(1), 69-119.

Conroy, Hector V. (2007) "The Role of Attitudes Toward Risk in the Decision to Migrate," California Center for Population Research, UCLA, working draft.

Daveri, Francesco and Riccardo Faini (1999) "Where Do Migrants Go?" Oxford Economic Papers 51(4), 595-622.

Dohmen, Thomas, Armin Falk, David Huffman, Uwe Sunde, Jürgen Schupp, and Gert G. Wagner (2005) "Individual Risk Attitudes: New Evidence from a Large, Representative, ExperimentallyValidated Survey,” IZA Discussion Paper 1730, September.

Dohmen, Thomas, Armin Falk, David Huffman, Uwe Sunde, Jürgen Schupp, and Gerd G. Wagner (2007) "Risk as a Personality Trait: On the Stability of Risk Attitudes," mimeo.

Dohmen, Thomas, Armin Falk, David Huffman, and Uwe Sunde (2006) "The Intergenerational Transmission of Risk and Trust Attitudes," IZA Discussion Paper 2380, October.

Fehr, Ernst, Urs Fischbacher, Michael Naef, Jürgen Schupp and Gert G. Wagner (2006) "A Comparison of Risk Attitudes in Germany and the U.S.," mimeo, Institute for Empirical Research in Economics, University of Zurich.

Gottschalk, Peter and Timothy M. Smeeding (1997) "Cross-National Comparisons of Earnings and Income Inequality," Journal of Economic Literature, 35(2):633-687.

Greenwood, Michael J. (1997) "Internal Migration in Developed Countries,” in Mark R. Rosenzweig and Oded Stark, eds., Handbook of Population and Family Economics, 647-720. Amsterdam: Elsevier.

Heitmueller, Axel (2005) “Unemployment Benefits, Risk Aversion, and Migration Incentives,” Journal of Population Economics 18(1), 93-112.

Jaeger, David A., Holger Bonin, Thomas Dohmen, Armin Falk, David Huffman, and Uwe Sunde (2007) "Direct Evidence on Risk Attitudes and Migration," IZA Discussion Paper 2655, February.

Katz, Eliakim and Oded Stark (1986) "Labor Migration and Risk Aversion in Less Developed Countries," Journal of Labor Economics 4(1), 134-149.

Levhari, David and Oded Stark (1982) "On Migration and Risk in Less Developed Countries," Economic Development and Cultural Change 31(1), 191-196.

Smith, Terence R. (1979) "Migration, Risk Aversion, and Regional Differentiation," Journal of Regional Science 19(1), 31-45.

Xu, Chenggang (1992) "Risk Aversion, Rural-Urban Wage Differentiation, and Migration," Centre for Economic Performance Discussion Paper 108, November. 
Figure 1

General Risk Attitudes for Movers and Stayers

2000-2006

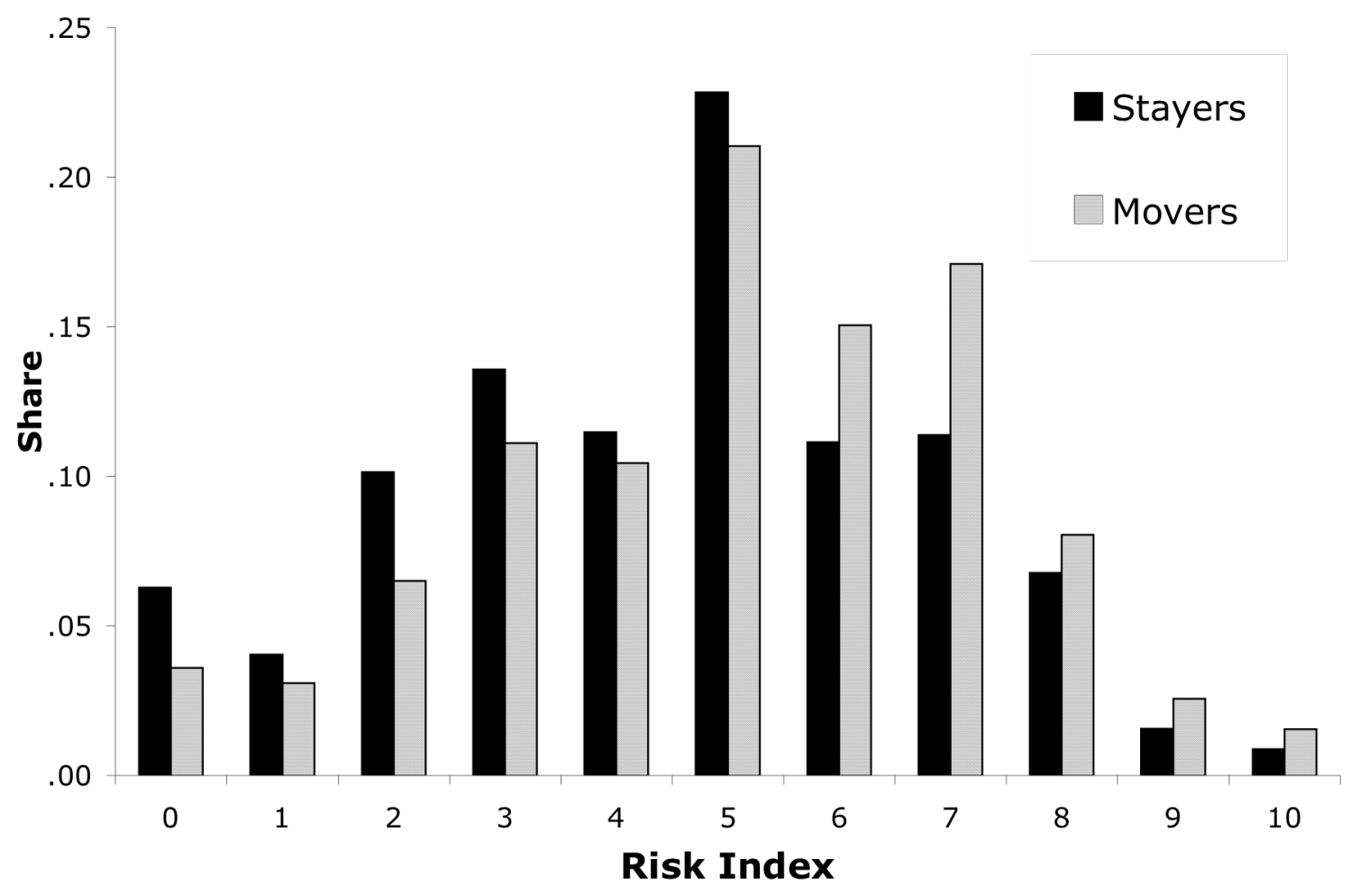

Source: Authors' tabulations from the 2000-2006 waves of the SOEP. The index is an individual's response to a question in the 2004 waves of the SOEP asking about "willingness to take risks, in general" on a scale from 0 to 10 , where 0 indicates "unwilling to take risks" and 10 indicates "very willing to take risks." Movers are individuals who changed region at least once between 2000 and 2006. Sample size is 10,115 . 
Figure 2

Is Migration as a Risky Endeavor?

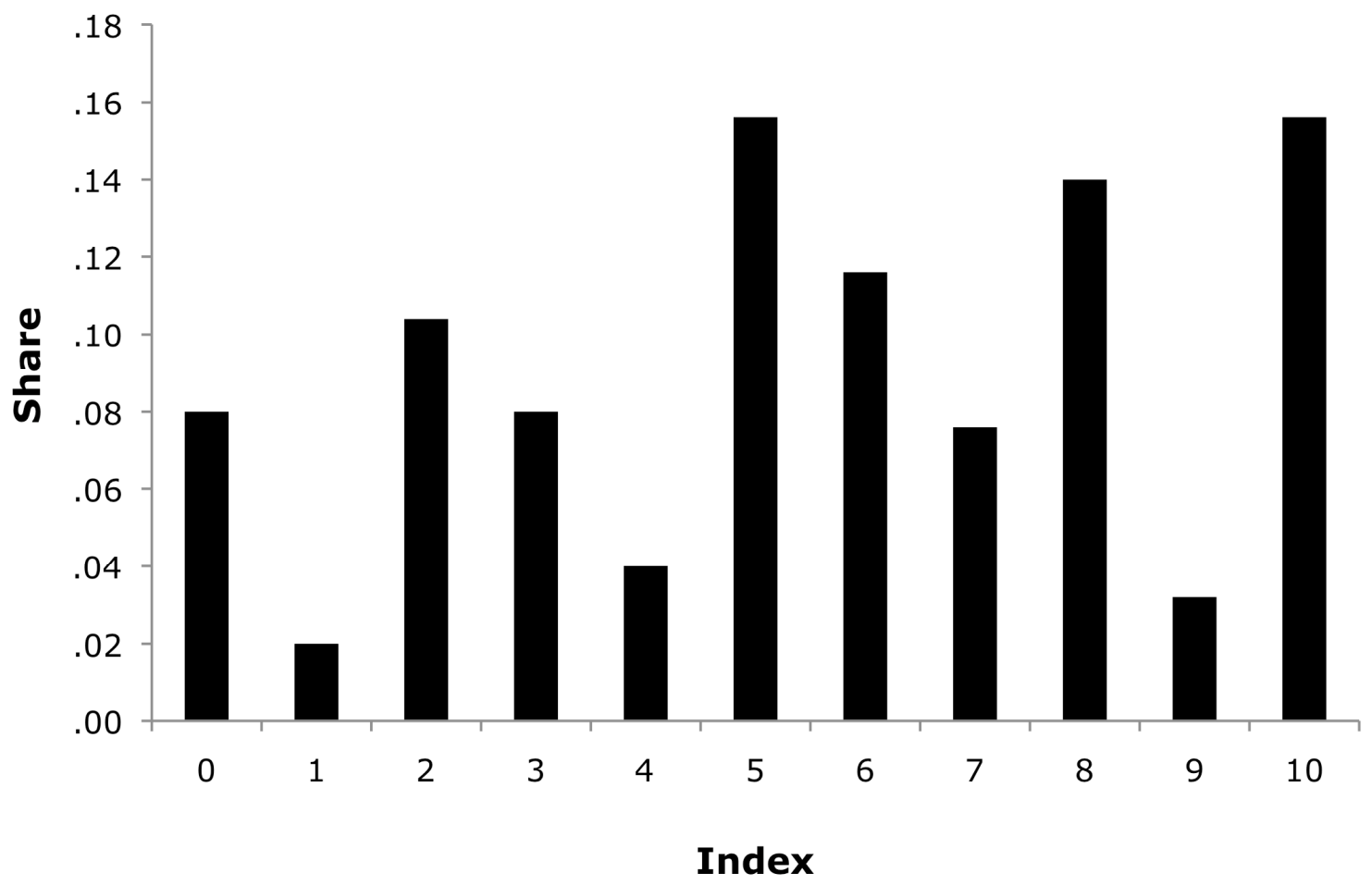

Source: Authors' tabulations from the pre-test for the 2008 wave of the SOEP. Respondents were asked "To what extent do you agree with the following statement: In general, moving between towns is associated with taking a risk." Responses were coded on a scale from 0 to 10, with 0 meaning "do not agree at all" and 10 meaning "perfectly agree". Sample size is 250. 
Table 1

Average Measures of Risk Attitudes for Stayers and Movers

\begin{tabular}{|c|c|c|c|c|c|c|c|}
\hline & \multicolumn{2}{|c|}{$\begin{array}{c}\text { Average of } \\
\text { Risk Index for }\end{array}$} & \multicolumn{2}{|c|}{$\begin{array}{c}\text { Share with } \\
\text { Risk Indicator=1 }\end{array}$} & \multicolumn{2}{|c|}{$N$} & \multirow{2}{*}{$\begin{array}{c}\text { Share } \\
\text { Movers }\end{array}$} \\
\hline & Stayers & Movers & Stayers & Movers & Stayers & Movers & \\
\hline All & 4.482 & 5.089 & .317 & .443 & 9,570 & 585 & .058 \\
\hline One move & & 5.000 & & .418 & & 491 & \\
\hline Two or more moves & & 5.553 & & .574 & & 94 & \\
\hline \multicolumn{8}{|l|}{ Sex } \\
\hline Men & 4.946 & 5.443 & .400 & .509 & 4,554 & 273 & .057 \\
\hline Women & 4.061 & 4.779 & .241 & .385 & 5,016 & 312 & .059 \\
\hline \multicolumn{8}{|l|}{ Age (in 2000) } \\
\hline $18-25$ & 4.966 & 5.156 & .406 & .439 & 929 & 173 & .157 \\
\hline $26-35$ & 4.631 & 5.285 & .335 & .491 & 2,409 & 228 & .086 \\
\hline $36-45$ & 4.522 & 4.800 & .320 & .400 & 2,996 & 115 & .037 \\
\hline $45+$ & 4.196 & 4.754 & .275 & .362 & 3,236 & 69 & .021 \\
\hline \multicolumn{8}{|c|}{ Years of education (in 2000) } \\
\hline $1-9$ & 3.652 & 4.704 & .219 & .463 & 1,066 & 41 & .037 \\
\hline $10.5-11$ & 4.376 & 5.010 & .294 & .429 & 2,926 & 98 & .032 \\
\hline $11.5-13$ & 4.629 & 5.050 & .327 & .421 & 3,519 & 259 & .069 \\
\hline $13.5+$ & 4.814 & 5.267 & .382 & .476 & 2,059 & 187 & .083 \\
\hline \multicolumn{8}{|l|}{ Married (in 2000) } \\
\hline No & 4.787 & 5.327 & .363 & .470 & 3,079 & 385 & .111 \\
\hline Yes & 4.338 & 4.630 & .295 & .390 & 6,491 & 200 & .030 \\
\hline \multicolumn{8}{|l|}{ Place of origin } \\
\hline Western Germany & 4.526 & 5.197 & .320 & .472 & 5,613 & 335 & .056 \\
\hline Eastern Germany & 4.735 & 5.075 & .343 & .413 & 2,679 & 201 & .070 \\
\hline Abroad & 3.763 & 4.408 & .250 & .367 & 1,278 & 49 & .037 \\
\hline \multicolumn{8}{|l|}{ Reasons for moving } \\
\hline Family & & 5.418 & & .496 & & 244 & \\
\hline Jobs & & 5.144 & & .457 & & 313 & \\
\hline Housing & & 5.005 & & .437 & & 213 & \\
\hline Other & & 5.110 & & .428 & & 91 & \\
\hline
\end{tabular}

Source: Authors' tabulations from the 2000-2006 waves of the SOEP.

Note: Movers are individuals who changed region at least once between 2000 and 2006.

The risk index is an individual's response in the 2004 wave of the SOEP to a question asking about "willingness to take risks, in general" on a scale from 0 to 10 , where 0 indicates "unwilling to take risks" and 10 indicates "very willing." Risk indicator is a binary variable, which is 1 when the risk index is 6 or greater. Reasons for moving are not exclusive categories; individuals can specify more than one reason. 
Table 2

Risk Attitudes and the Probability of Migrating between 2000 and 2006

\begin{tabular}{|c|c|c|c|c|c|c|}
\hline Covariates & (1) & (2) & (3) & (4) & (5) & (6) \\
\hline Risk index & $\begin{array}{c}.0064 \\
(.0010)\end{array}$ & $\begin{array}{c}.0042 \\
(.0009)\end{array}$ & $\begin{array}{c}.0026 \\
(.0009)\end{array}$ & & & \\
\hline Risk indicator & & & & $\begin{array}{c}.0312 \\
(.0053)\end{array}$ & $\begin{array}{c}.0210 \\
(.0047)\end{array}$ & $\begin{array}{r}.0149 \\
(.0044)\end{array}$ \\
\hline Age (2000) & & $\begin{array}{l}-.0032 \\
(.0019)\end{array}$ & $\begin{array}{l}-.0023 \\
(.0002)\end{array}$ & & $\begin{array}{l}-.0032 \\
(.0002)\end{array}$ & $\begin{array}{l}-.0023 \\
(.0002)\end{array}$ \\
\hline Female & & $\begin{array}{c}.0039 \\
(.0041)\end{array}$ & $\begin{array}{c}.0042 \\
(.0039)\end{array}$ & & $\begin{array}{c}.0035 \\
(.0041)\end{array}$ & $\begin{array}{c}.0042 \\
(.0038)\end{array}$ \\
\hline Married (2000) & & & $\begin{array}{l}-.0405 \\
(.0054)\end{array}$ & & & $\begin{array}{l}-.0407 \\
(.0054)\end{array}$ \\
\hline Years of education (2000) & & & $\begin{array}{r}.0057 \\
(.0007)\end{array}$ & & & $\begin{array}{r}.0057 \\
(.0007)\end{array}$ \\
\hline \multicolumn{7}{|l|}{ Place of origin } \\
\hline Western Germany & & & ref. & & & ref. \\
\hline Eastern Germany & & & $\begin{array}{c}.0079 \\
(.0045)\end{array}$ & & & $\begin{array}{r}.0081 \\
(.0045)\end{array}$ \\
\hline Abroad & & & $\begin{array}{l}-.0037 \\
(.0063)\end{array}$ & & & $\begin{array}{l}-.0043 \\
(.0062)\end{array}$ \\
\hline Pseudo- $R^{2}$ & .0089 & .0712 & .1046 & .0105 & .0715 & .1055 \\
\hline
\end{tabular}

Source: Authors' tabulations from the 2000-2006 waves of the SOEP.

Note: Entries in table are marginal effects from probit estimation, evaluated at sample means. Standard errors in parentheses. The risk index is an individual's response in the 2004 wave of the SOEP to a question asking about "willingness to take risks, in general" on a scale from 0 to 10 , where 0 indicates "unwilling to take risks" and 10 indicates "very willing to take risks." Risk indicator is a binary variable, which is 1 when the risk index is 6 or greater. Mean of dependent variable is .058. Sample size is 10,155. 
Table 3

Are Risk Attitudes Affected by Migration?

\begin{tabular}{lccccc}
\hline & Mean of & & & \\
Dependent & & \multicolumn{2}{c}{ Marginal Effects } \\
\cline { 3 - 5 } Dependent Variable and Covariates & $N$ & Variable & $(1)$ & $(2)$ & $(3)$ \\
\hline
\end{tabular}

Effect of Risk Index (2004) on
a) Ever moved, 2000-2004
10,155
.044
.0048
.0030
.0017
(.0009)
(.0008)
(.0007)
b) Moved, 2004-2006
10,155
.019
.0026
.0017
.0011
(.0006)
$(.0005)$
$(.0005)$
c) Moved, 2004-2006, no prior moves
9,706
.014
.0017
.0012
.0008
(.0005)
(.0005)
(.0005)

Effect of Ever Moved, 2004-2006, on

c) Change in Risk Index, 2004-2006

10,108

0.285

$-.2493$

$-.1939$

$-.1123$

(.2653)

(.2658)

(.2643)

d) Risk Index 2006, including

10,108

4.784

.2463

.1785

.1624

Risk Index 2004 as a covariate

(.2343)

(.2352)

(.2360)

\section{Covariates}

Age, female

Origin, married, years of education

Yes

Yes

Yes

Source: Authors' tabulations from the 2000-2006 waves of the SOEP.

Note: Standard errors in parentheses. Entries in rows a)-c) are marginal effects from probit estimation, evaluated at sample means. Entries in rows c) and d) are coefficients from OLS estimation. The risk index is an individual's response to a question asking about "willingness to take risks, in general" on a scale from 0 to 10 , where 0 indicates "unwilling to take risks" and 10 indicates "very willing to take risks." Covariates measured at beginning of period (i.e. in 2000 and 2004). 